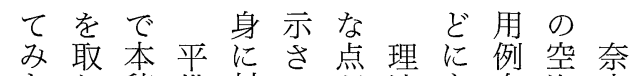
二たり稿備対れ永法も自海良 文、上でにすすた多身見体な時 玄弉て、い解成が智れ奈に柋 訳こて 釈成、法可良先期

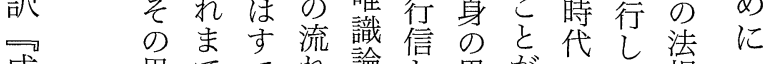
成思ででれ論思がのて相 唯想学に界説平想既言理宗 史界あ汲説備全に論法の 的にるんにに体報の身行 意末程だも関の告智身信 義報度思と产形さ䈍づる成智市 つの討でく限過て、法備 い行があ、全程い信方の て信なる 茬の金基つ方国用著 年理れ評明基い例に の法て価経慧て 自智る。る所に説よ代 の認平 述法そ身こ の 法て明権る 初

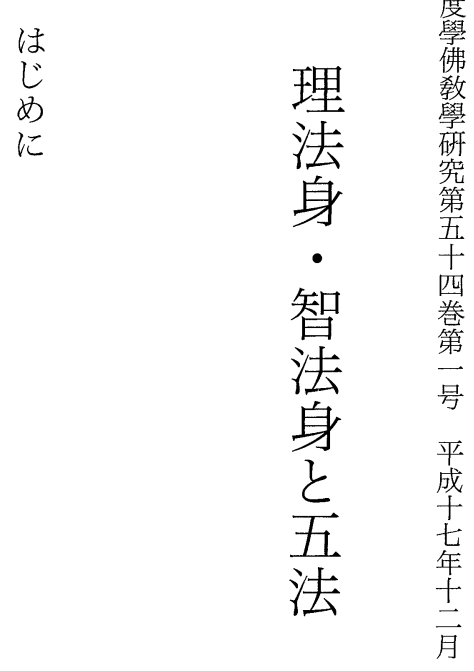

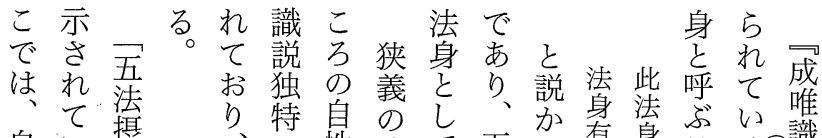

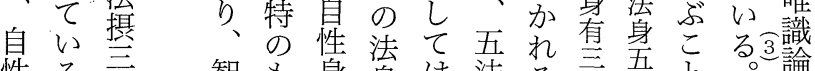
性る身 智も身身は法る睊五法と論 身が身門切の清と文法別㕣に本で

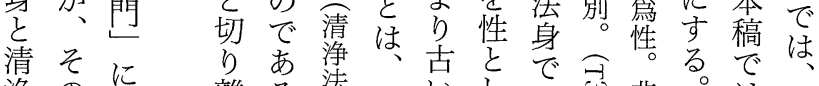
浄の法う吾離る。界五伝し、志非広は法足 界ち五法狭法統三る。己淨広便身

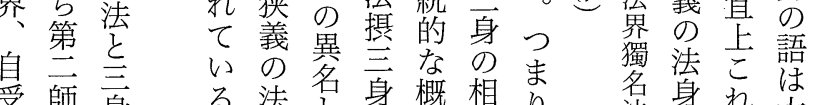
受師身 る 法名身概相 り 名身杂法立

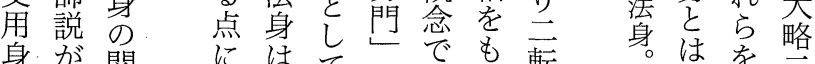

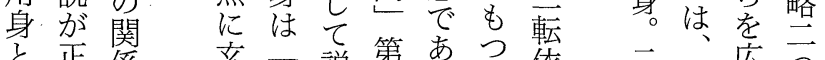

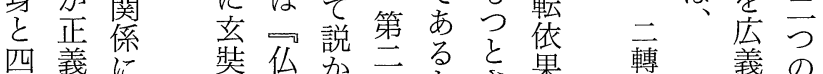
智とつの地れ師点さ果依の意 とさい特経る説言れ态皆法意

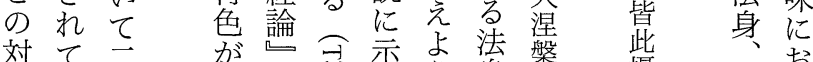

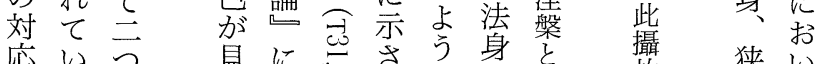
応いら見に忍さう。身兄攝 狭い

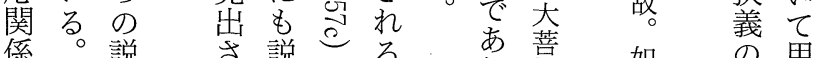

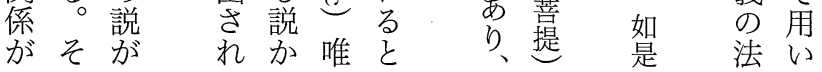


と有二

自為師説 全

理受無説加金

法用為に光四

身身功もて 経 基

智合先る

法わをい会せ基豆乗

主たお合て、基身莱

法仏せ清金対苑

足苾た浄金す

立る の、界経解章

とつと秎ま

釈 り 四法

ᄂ 五 四身三

法智を身

こあ品こ義

のる常成 林

よい遍唯

うは色識に

な自身論ま

法 性 真 と

身身実第 め
い 現み

る す が 法

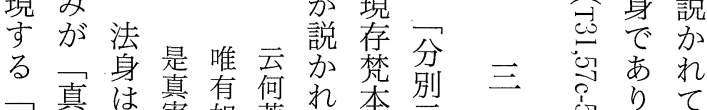

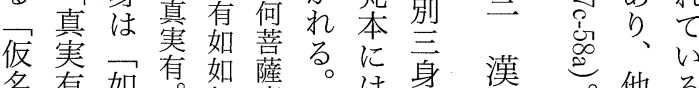

名有如有如薩。如身漢法他 る

でと前智隡身け尔用つ

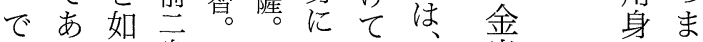

あり如身是了つい漠光り

る、智而名知いる漢明変五

と応旦作法法て。訳経化法

い・で根身身は本で䋈身と

う化あ本。前為员品直

二のるこ前為下古真分 智接

重云と寻示除 の諸上諦別結

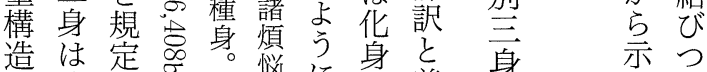

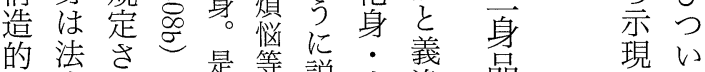

な身れ假障説応浄品导て

三をる 名架身訳るい

身根。有為机・の仏る

説本ま具る。法み身の

なし法第善のああさこ

つて身 帛法 三つれの

て顕の 身故鬲て 身元
点う身経

慧 がなを慧

沼今不心障些見解合の沼

は滒爾品明法ら秎わ法は

法就忩為身れ得有る基た身知

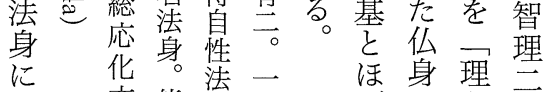

は亦能身自染でと合

自 名詓所為法 智吕

性身證具身。

法故名羓二

身故名 法 云

と唯 身 明 徳

功云佛得 身

徳如㫪德今

法如是類身合

の身有 即 䔬 浄 為

種 奉贫法 為

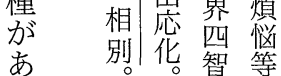

の述まと
でつに法

あ 它よ 身

が

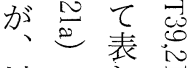

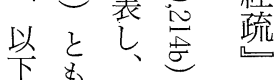

記べた述

述て自心゙

に基る 身て

兾こ自金

なの受光

るよ用明
い明経名名を表を

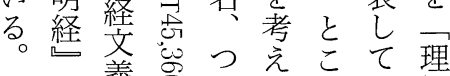
説義导まるららい智 を理無りたがる冥 認無で狭め基。合 め爽な義、基吕 ざつけすの法、点 を岁ば身文成恕 なこらな清識的 いとなけ浄論文 い述と法第界 うて述なそ云て 中経て ずも説 理 半文い、のだ省 端でる。無でけ 智 な 結る 最為 る 論以終の自づ語 に上的德性いに 至㥁身てよ こ金基本 の異身告 


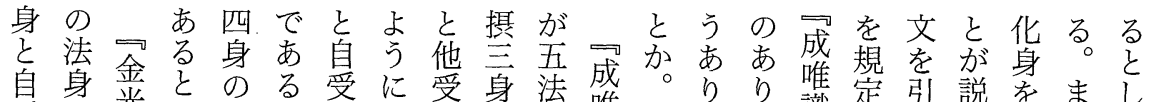

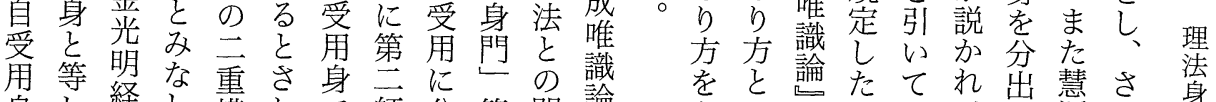

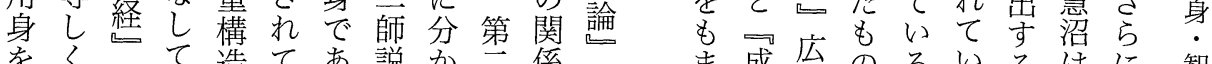
をくのて造て あ説か自係に成広のるいるはに智

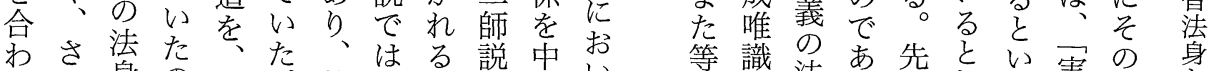

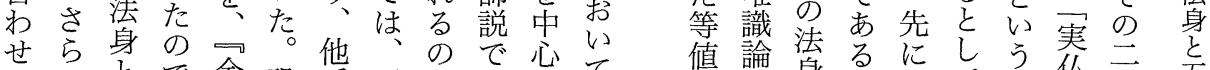

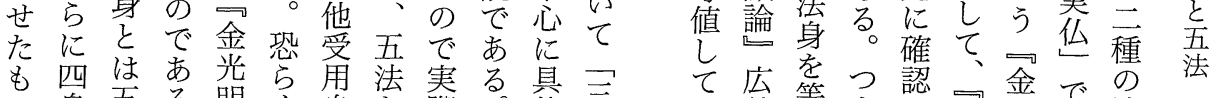

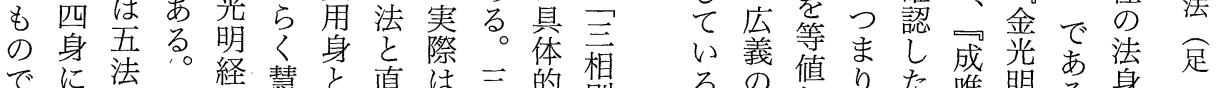

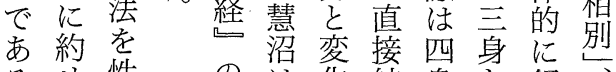
るせ性の沿結身と叙

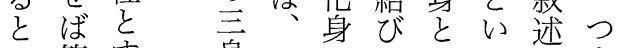
い第す身こはつなっさま うる尚の智いるてれ り の師 $\rightarrow$ 五加てもて三 が説成重法らいす受的身 慧に唯構を示るで用る向 沼扮識造中現のに身の相 のけ論と心市は確はがの 理る同とる自認自学 解自広じし仏性し受五り の性義でた身身た用法方

るの值りた唯明る身 の法た慧よ識経法架立 で身た沼う論足身五 あがざはに迹の方法 。身、金こ、身仮総 この金光の法の仏て 机相光明文身あ㕕を はを明経は有りで含 ぞ有経这店方交 う专里の義相とると いるの法の別同忘し うと言身法じ身て

説

説

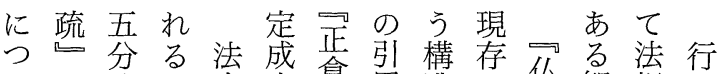
小測气理言いは洼号身立良用造守侻智相信 乗はす洼法て基身法に年院やをる説星教は

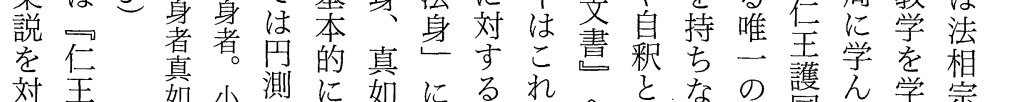

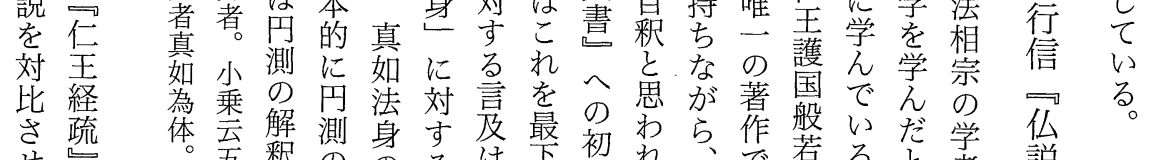

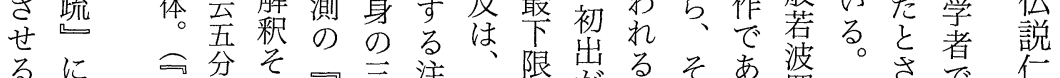

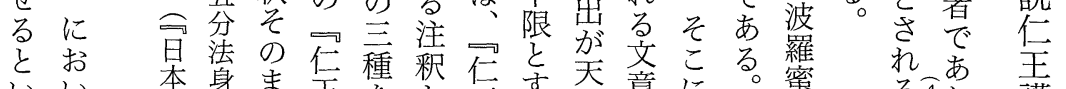

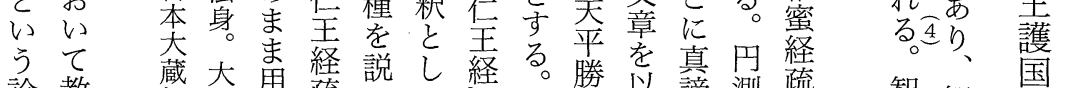

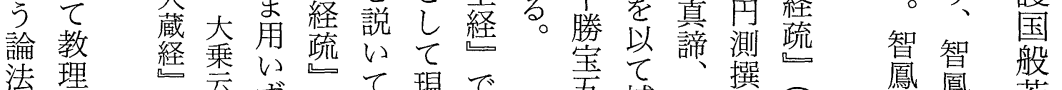

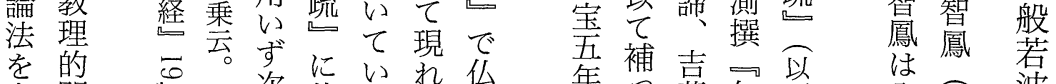

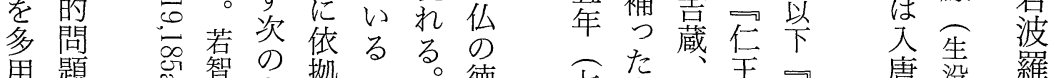

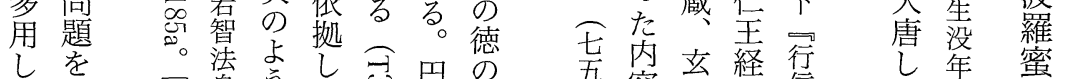

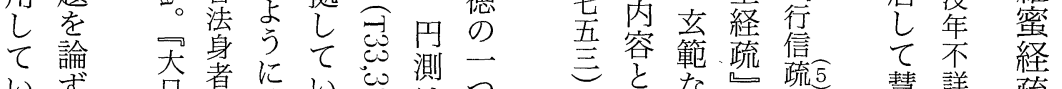

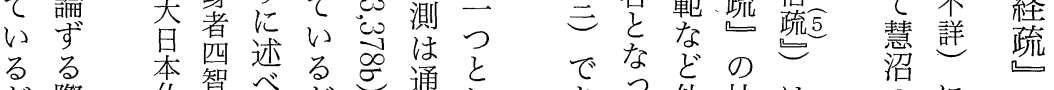

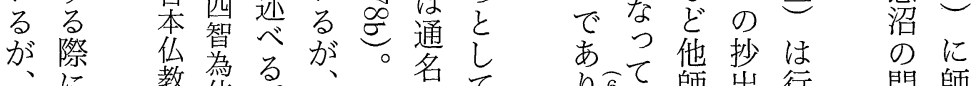

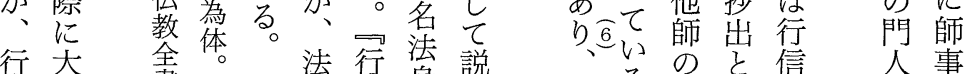

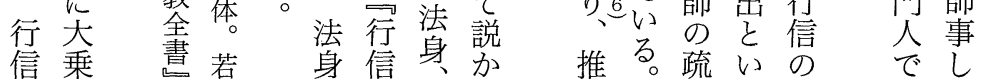


師に三お 対 説射け专慧

理に金のるる沼

法お光三五新は

け明重法た基

る経構をなを

智自造中解継

法性のと心釈承

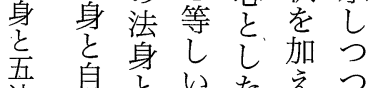

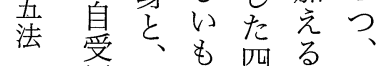

足 立
る。は自に基 め智角成 基 节方身唯 金 坴切合䧕光 明離せ—経 経さ離せ五経 わ仏法の

のた身摂法

法匹无身 身成あ身を 認識を門理 め論 解第 と る 釈云智 こ狭し師皆 と義て説に にのいによ は法るおり 難身。けて ををとる表 し義 ろ性と て が身と 第質経師治身 二的のにに w基と छ

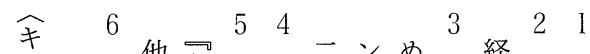
ワ 東疏伀主要本吾

1 大学䙵朝

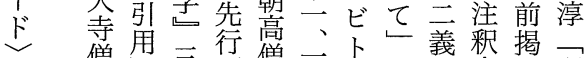
僧用三行僧二卜七義釈揭理

理教只究运九哲学法類交法

法輪企二

身経正九以大六。身研に中拙と 奉学九旦究つ心稿智

智奉学九を本の請无いに法

法啓学拙照教種九は空良身

天身管院拙照教種九嘧良口

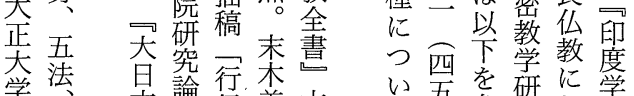
本集信美六て五参研に学 紜行古焦の文至て!窟究抬仏

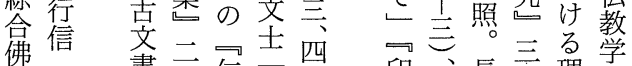
教

研

究

研

究

生 書忈仁云四印、長主理学 二三経本上度学九雅揭法聟 二 $\vec{\bigcirc}$ 絓流 四四に宗

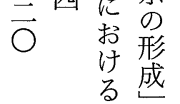
仏七人載身五 教 。学茅定云 学ル研定最二 究へ論椦

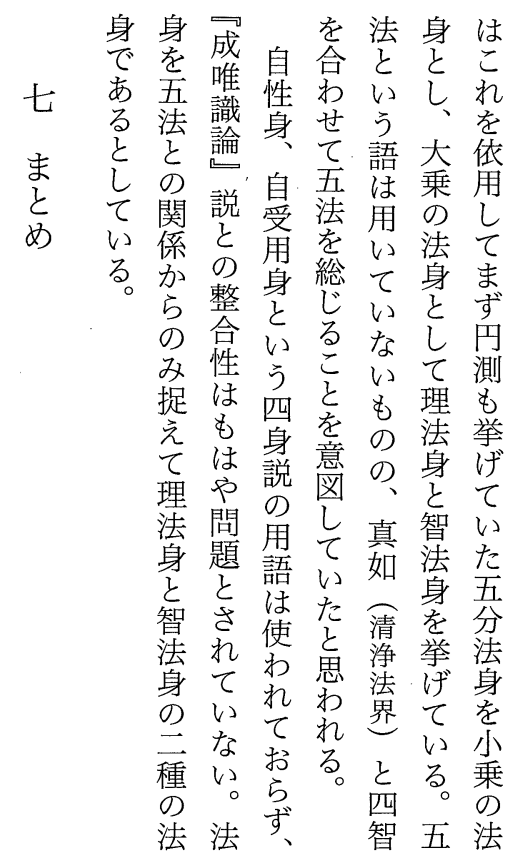

い教想き—のとは

つ理はる旦概 等直 行 たの、だは念值接信 の固奈乃切をし的は で定良うり通たに五 は化時。離じ慧は法 なが代行さて沼っに い進末信れ両の金よ かむ期なた要考光つ とに以ぞ智素え明て 思つ降にを方経理 われ宗見再分の法 れて、派らび離流の身 る。内法敨法. 次外る身心を身智 第とよにう汲と法 にのう引引事む射 異論なき態も成を 説争理戻を戀の唯定 とを法し内で識義 し通身たにあ論し て じ排て智の抱り、広い 除法法と評た理義る。 れ宗の価ま智法こ 


\section{the Taikyōhyakuren-shō}

Keijun KANEKO

The paper is mainly intended to make clear the faith of Jokei, a Buddhist priest of the Japanese Hossō sect, in Prince Shōtoku. It is necessary at first to decide the authorship of the three works preserved in the Taikyohyakuren$s h \bar{o}$. If these works were really written by Jōkei, following his view of the prince as the incarnated goddess of mercy, we could verify his strong faith that the life of the prince is likened to Buddha. Jōkei again accepts the prince as being one who contributed to the prosperity of the Hossō sect.

54. The Pañca-dharma and the Dharma-kāya associated with $R i$ (理) and Chi (智)

Toshihiro ADACHI

Gyōshin, who belonged to the Hossō-shū in the Nara era, had a peculiar view of hosshin (法身, dharma-kāya) that was associated with ri (理) and chi (智). In the Ninnōkyōsho, he postulated that ri-hosshin (理法身) had the nature of shinnyo (真如, tathatā) and chi-hosshin (智法身) had the nature of shichi (四智, catvārijñānāni). However, it has never been reported that Gyōshin possesses a view such as the one indicated above. A background of his thinking can be found in Huizhao's Jinguangming zuishengwang jingshu. Huizhao described the Dharmakāya of the Jinguangming zuishengwang jing through the words $r i$ and chi, and equated it with the Dharmakāya in the broader perspective of Chengweishi lun whose nature was explained to be like that of the five elements (五法, pañca-dharma).

\section{Observations on the Texts Quoted in Myōe's Zaijarin and Shōgonki}

Mieko YONEZAWA

Zaijarin (1212) and Shōgonki (1213) were written by Myōe (1173-1232) as a series of critiques of Hōnen's (1133-1212) Senchakushū (1198). At the begin- 